\title{
PERKEMBANGAN DAN URGENSI INSTRUMEN HUKUM ADMINISTRASI PASCA PENETAPAN UNDANG-UNDANG NOMOR 2 TAHUN 2020 PADA MASA PANDEMI COVID-19
}

\author{
A. Sakti R. S. Rakia \\ Dosen Fakultas Hukum, Universitas Muhammadiyah Sorong \\ Email Korespondensi: saktialwiyah@um-sorong.ac.id
}

\begin{abstract}
Abstrak. Penyebaran Covid-19 diprediksi akan membentuk regulasi-regulasi dengan ragam jenis dan hierarki, berpotensi memundurkan semangat penyederhanaan regulasi. Disamping itu, penyebaran pandemi Covid-19 telah menyebabkan kejenuhan publik. Disamping itu hukum administrasi menjadi urgen dan berkembang sejak penetapan UU No. 2 Tahun 2020. Penelitian ini bertujuan untuk mengetahui kedudukan instrumen hukum administrasi dalam pembentukan kebijakan publik, serta menganalisis perkembangan dan urgensi hukum administrasi sebagai alternatif kebijakan pemerintah pada masa pandemi Covid-19. Tipe penelitian yang digunakan dalam penelitian ini adalah normatif-yuridis dengan spesifikasi bersifat deskriptifanalitis. Teknik analisis dilakukan secara kualitatif guna menjawab permasalahan hukum yang dihadapi. Kesimpulan penelitian ini adalah, sejak penetapan UU No. 2 Tahun 2020, hukum administrasi berkembang cepat selama pandemi Covid-19 berdasarkan beberapa indikator. Saran dalam penelitian ini adalah perlu dibentuk instrumen hukum yang materi muatannya berlaku sekali selesai agar tidak terjadi residu aturan.
\end{abstract}

Kata Kunci: Covid-19; Hukum Administrasi; Perkembangan Hukum; Urgensi Hukum.

artikel dengan akses terbuka dibawah lisensi CC BY -4.0

\section{PENDAHULUAN}

Selama lebih dari setahun, penyebaran virus Covid-19 telah melanda dunia, termasuk Indonesia. Belum dapat dipastikan kapan akan berakhir, sehingga berujung pada kondisi yang mengharuskan penyesuaian besar-besaran di setiap dimensi kehidupan manusia. Sebuah tulisan berjudul Covid-19: The Great Reset yang ditulis oleh Klaus Schwab dan Thierry Malleret, dalam uraian kritisnya menyatakan bahwa Covid-19 merupakan masalah yang serius dan bukanlah suatu argumentasi hiperbola, dimana dalam argumennya menyatakan bahwa: ${ }^{1}$

"We cannot be accused of hyperbole when we say it is plunging our world in its entirety and each of us individually into the most challenging times we've hlm. 8 .

${ }^{1}$ Klaus Schwab \& Thierry Malleret. (2020). Covid-19: The Great Reset. Switzerland: Forum Publishing,

DOI: https://doi.org/10.37276/sjh.v2i2.106 
faced in generations. It is our defining moment - we will be dealing with its fallout for years, and many things will change forever (Kita tidak dapat dituduh hiperbola ketika kita mengatakan itu menjerumuskan dunia kita secara keseluruhan dan masing-masing dari kita secara individu ke dalam saat-saat paling menantang yang kita hadapi dari generasi ke generasi. Ini adalah momen yang menentukan - kita akan menghadapi konsekuensinya selama bertahun-tahun, dan banyak hal yang akan berubah selamanya)."

Dampak penyebaran Covid-19 tidak hanya mengganggu stabilitas ekonomi, geopolitik, sosial, teknologi, ataupun lingkungan hidup, namun juga memberi pengaruh terhadap pembentukan maupun penegakkan hukum. Beberapa penegakan hukum dalam berbagai dimensi hukum telah bergeser dan ditegakkan tanpa sepenuhnya mengacu pada peraturan perundang-undangan, karena dianggap tidak memadai dalam situasi pandemi. Misalnya, pengadilan virtual di era pandemi, ${ }^{2}$ pendaftaran gugatan online di era pandemi, ${ }^{3}$ ataupun mengenai optimalisasi penerimaan pajak di era pandemi ${ }^{4}$ merupakan realitas yang relatif baru dalam penegakan hukum di Indonesia. Belum ditentukan apakah pemberlakuan dan penegakan hukum tersebut akan berakhir atau hanya selama masa pandemi. Di sisi lain, perubahan karakter penegakan hukum sedikit banyak akan berdampak pada institusi negara maupun masyarakat dalam aktivitas hukumnya.

Ancaman dari penyebaran Covid-19 diperkirakan secara bertahap akan mengkondisikan para pembentuk regulasi untuk membentuk peraturan perundang-undangan dari berbagai jenis dan hierarki. Sejak disahkannya Undang-Undang Republik Indonesia Nomor 2 Tahun 2020 tentang Penetapan Peraturan Pemerintah Pengganti UndangUndang Nomor 1 Tahun 2020 tentang Kebijakan Keuangan Negara dan Stabilitas Sistem Keuangan untuk Penanganan Pandemi Corona Virus Disease 2019 (Covid-19) dan/atau Dalam Rangka Menghadapi Ancaman yang Membahayakan Perekonomian Nasional dan/atau Stabilitas Sistem Keuangan Menjadi Undang-Undang (selanjutnya disebut UU No. 2 Tahun 2020), beberapa aturan teknis yang bersifat mengatur dengan berbagai jenis dan hierarki juga dibentuk atas atribusi dari Undang-Undang a quo. ${ }^{5} \mathrm{Hal}$ ini belum termasuk jenis ataupun bentuk peraturan di luar dari yang diatribusikan oleh UndangUndang Nomor 2 Tahun 2020. Misalnya, Perpu Pilkada, Instruksi Presiden, Instruksiinstruksi Menteri, ataupun Peraturan-Peraturan Kepala Daerah, yang jumlah minimalnya cenderung sama dengan jumlah daerah otonom yang ada di Indonesia.

\footnotetext{
${ }^{2}$ Sandhy Handika., Muhammad Ibnu Fajar Rahim., \& Rudi Pradisetia Sudirdja. (2020). Virtual Court Policy For Criminal Justice on Corona Virus Disease Pandemic. Substantive Justice International Journal of Law, Universitas Muslim Indonesia, 3(1), hlm. 76.

${ }^{3}$ Ide Prima Hadiyanto. (2021). Pendaftaran Gugatan Online di Pengadilan di Era Pandemi Covid-19. Jurnal Ilmiah Fenomena, Universitas Abdurachman Saleh, 18(1), hlm. 2049.

${ }^{4}$ Lutfia Rizkyatul Akbar. (2020). Analisis Kinerja Direktorat Jendral Pajak dalam Optimalisasi Penerimaan Pajak di Era-Pandemi Covid 19. JABE (Journal of Applied Business and Economic), Universitas Indraprasta PGRI, 7(1), hlm. 101.

${ }^{5}$ Sedikitnya terdapat 15 (lima belas) ketentuan dalam UU No. 2 Tahun 2020 yang mengatur mengenai atribusi kewenangan kepada Peraturan Menteri, Peraturan Pemerintah, Peraturan Presiden, Peraturan Bank Indonesia, serta Peraturan Otoritas jasa Keuangan. Selain itu, terdapat pula jenis peraturan lainnya seperti Instruksi Presiden, Instruksi Menteri, Peraturan Kepala Daerah, maupun beragam Surat Edaran.
} 
Misalkan masalah pandemi Covid-19 belum dinyatakan terselesaikan, dan negara menganggap perlu adanya regulasi. Dalam hal itu, undang-undang kemungkinan besar akan dibentuk lagi sebagai upaya dan wujud legitimasi kebijakan pemerintah. Akan tetapi, sebagaimana diketahui bersama bahwa waktu dan anggaran yang dibutuhkan untuk membentuk suatu undang-undang relatif lama jika menggunakan prosedur legislasi biasa. Di sisi lain, jika kita memperhatikan Program Legislasi Nasional (Prolegnas) 2020-2024, ${ }^{6}$ belum ada pembentukan dan penyusunan RUU terkait Covid-19. Namun, misalkan opsi pembentukan peraturan terkait Covid-19 dikategorikan dalam Prolegnas Super Prioritas. ${ }^{7}$ Dalam hal ini, hal tersebut dapat menimbulkan permasalahan, terutama tentang dasar hukum pembentukannya yang masih menjadi kontroversial di kalangan publik.

Pembentukan peraturan-peraturan dengan beragam jenis dan hierarki pada masa pandemi, berpeluang mengendorkan semangat penyederhanaan peraturan yang saat ini tercermin dalam beberapa kebijakan negara. Proses simplifikasi terhadap peraturan tidak hanya untuk menghindari timbulnya over-regulation, tetapi juga untuk memberikan rasa aman dan nyaman terhadap setiap subjek hukum dalam lalu lintas hukum. Justru dengan kondisi pandemi saat ini, upaya paling logis dan konsisten yang harus dilakukan adalah meningkatkan penyederhanaan peraturan, yang bertujuan untuk mengatasi kejenuhan sosial yang timbul selama masa pandemi Covid-19.

Salah satu upaya yang dapat dilakukan untuk menyederhanakan peraturan-peraturan adalah dengan menggunakan instrumen-instrumen hukum dalam lingkup hukum administrasi negara. Selain sebagai penyempurna dari konsep ketatanegaraan, instrumen hukum administrasi negara memiliki keunggulan dalam pembentukan kebijakan negara yang dapat dibentuk dengan waktu dan biaya yang relatif ringan. Bahkan dapat dikatakan bahwa tanpa hukum administrasi, kebijakan pemerintahan yang telah ditetapkan tidak dapat dilaksanakan. Sebaliknya, meskipun tanpa didahului oleh peraturan hukum tertentu, hukum administrasi dapat membentuk peraturan dengan kewenangan Diskresi dan sama efektifnya dengan peraturan hukum lainnya. Hal ini tentu saja sangat penting untuk mengatasi keadaan rechtsvacuum.

Berdasarkan Pasal 1 angka 9 Undang-Undang Republik Indonesia Nomor 30 Tahun 2014 tentang Administrasi Pemerintahan (selanjutnya disebut UU No. 30 Tahun 2014), menjelaskan bahwa:

"Diskresi adalah Keputusan dan/atau Tindakan yang ditetapkan dan/atau dilakukan oleh Pejabat Pemerintahan untuk mengatasi persoalan konkret yang dihadapi dalam penyelenggaraan pemerintahan dalam hal peraturan perundang-undangan yang memberikan pilihan, tidak mengatur, tidak lengkap atau tidak jelas, dan/atau adanya stagnasi pemerintahan."

${ }^{6}$ Administrator. (2020, 10 Februari). Program Legislasi Nasional 2020-2024. Sekretariat Jenderal DPR RI. Diakses pada tanggal 12 Februari 2020.

${ }^{7}$ Pada dasarnya tidak ada istilah Prolegnas Super Prioritas dalam UU No. 15 Tahun 2019. "Prolegnas Super Prioritas" merupakan istilah yang digunakan sebagai kebijakan yang berfokus pada pembentukan beberapa undang-undang saja. Pemikiran ini timbul berdasarkan Pasal 3 ayat (4) Peraturan DPR No. 2 Tahun 2020. 
Selanjutnya, berdasarkan Pasal 22 ayat (2) UU No. 30 Tahun 2014, mengatur bahwa Setiap penggunaan Diskresi Pejabat Pemerintahan bertujuan untuk:

a. melancarkan penyelenggaraan pemerintahan;

b. mengisi kekosongan hukum;

c. memberikan kepastian hukum; dan

d. mengatasi stagnasi pemerintahan dalam keadaan tertentu guna kemanfaatan dan kepentingan umum.

Dari ketentuan di atas, dimungkinkan untuk menerapkan Diskresi selama pandemi Covid-19. Tak lain adalah untuk menyelesaikan berbagai persoalan yang muncul dalam penyelenggaraan pemerintahan, meski tanpa didahului atau dibentuk berbagai peraturan. Apabila diperhatikan, beberapa instrumen peraturan yang berkaitan dengan masa pandemi, sebagian besar berjenis peraturan-peraturan pelaksana (verordnung Satzung). Realitas ini membuktikan bahwa penggunaan peraturan kebijakan dalam mengatasi permasalah regulasi cukup relevan.

Namun pembentukan peraturan pelaksana berdasarkan pendelegasian UU No. 2 Tahun 2020 masih cenderung regulatif. Belum lagi dalam hal implementasi karena banyaknya regulasi saat terjadi pandemi, sehingga menimbulkan kebingungan bagi publik. Masalah ini dapat diminimalisir dengan penerapan UU No. 30 Tahun 2014, di mana instrumen hukum administrasi tidak hanya bersifat regelling tetapi juga bersifat beschikking. Instrumen hukum yang bersifat beschikkingen memiliki keunggulan tersendiri, yaitu materinya hanya berlaku sekali-selesai (einmaligh), dan berbeda dengan instrumen hukum yang bersifat regelling, yaitu materinya akan berlaku terusmenerus (dauerhaftig).

Instrumen hukum yang bersifat regelling memiliki residu hukum tersendiri, yaitu hambatan terkait penerapan peraturan tersebut jika materi muatannya telah dilaksanakan atau sudah tidak relevan lagi. Dalam situasi seperti itu, perlu dilakukan pencabutan peraturan yang tidak relevan, sebagaimana berdasarkan mekanisme yang berada pada lampiran Undang-Undang Republik Indonesia Nomor 15 Tahun 2019 tentang Perubahan Atas Undang-Undang Nomor 12 Tahun 2011 tentang Pembentukan Peraturan Perundang-Undangan (selanjutnya disebut UU No. 15 Tahun 2019). Dalam lampiran UU No. 15 Tahun 2019 dapat dilihat bahwa teknis pencabutan suatu peraturan cukup metodis, yang sedikit banyaknya akan menyita waktu dan biaya serta dapat menghambat proses legislasi tahunan yang telah direncanakan sebelumnya.

Proses pembentukan hukum dalam kerangka hukum administrasi dengan segala instrumennya relatif lebih cepat dibandingkan dengan proses legislasi yang konvensional. Berbagai instrumen hukum administrasi yang relatif cepat juga dapat meminimalisir psikologi publik yang akhir-akhir ini mengalami kejenuhan. ${ }^{8}$ Namun, proses penerapan hukum administrasi sarat dengan kepentingan para penguasa apabila

${ }^{8}$ James Boylan., et al. (2021). Boredom in the COVID-19 Pandemic: Trait Boredom Proneness, the Desire to Act, and Rule-Breaking. Personality and Individual Differences, Elsevier, 171, hlm. 3. 
tidak dijalankan sebagaimana mestinya, maka akan menimbulkan onrechtsmatigh overheidsdaads. Hal ini disebabkan oleh besarnya kewenangan pemerintah dalam memutuskan sebuah kebijakan.

Terdapat beberapa penelitian sebelumnya yang membahas peran pemerintah dan/ atau keberadaan hukum dalam menyikapi kondisi pandemi, di antaranya sebagai berikut.

Abdul Basid Fuadi, Zaka Firma Aditya, dan Rizkisyabana Yulistyaputri dalam abstrak penelitiannya menyatakan bahwa: ${ }^{9}$

"Di masa pandemi Covid-19 saat ini, pemerintah diharuskan membuat akselerasi-akselerasi kebijakan yang mendukung masyarakat. Namun sayangnya, kebijakan yang dibuat oleh pemerintah justru tidak konsisten dan saling bertentangan."

Aprista Ristyawati dalam abstrak penelitiannya menyatakan bahwa: ${ }^{10}$

"Pandemi global yang terjadi saat ini jelas menimbulkan kekhawatiran masyarakat. Oleh karena itu, Pemerintah harus memberikan perlindungan kepada masyarakat dalam pencegahan maupun penanganan kasus Covid-19 sesuai amanat Undang-Undang Dasar Negara Republik Indonesia Tahun 1945."

Isnaini Apri Dawati, Shinta Rukmi Budiastuti dalam abstrak penelitiannya menyatakan bahwa: ${ }^{11}$

"Peran hukum di saat pandemi berpengaruh terhadap apa yang akan dilakukan pemerintah terkait pencegahan dan penanggulangan bencana sebagai trobosan mewujudkan kesejahteraan masyarakat di tengah Covid-19."

Namun demikian, penelitian terdahulu sebagaimana telah dideskripsikan di atas tidak secara tegas menjelaskan urgensi dan perkembangan hukum administrasi di era pandemi Covid-19. Oleh karena itu, perkembangan dan urgensi instrumen hukum administrasi sebagai alternatif kebijakan hukum pada masa pandemi Covid-19 perlu ditelaah lebih lanjut.

Berdasarkan uraian pendahuluan di atas, maka penelitian ini bertujuan untuk mengetahui kedudukan instrumen hukum administrasi dalam pembentukan kebijakan publik, serta menganalisis perkembangan dan urgensi hukum administrasi sebagai alternatif kebijakan pemerintah pada masa pandemi Covid-19. Diharapkan agar hasil penelitian ini dapat

${ }^{9}$ Abdul Basid Fuadi., Zaka Firma Aditya., \& Rizkisyabana Yulistyaputri. (2020). Pentingnya Evidence Based Policy Making dalam Pembuatan Kebijakan Publik di Era Pandemi. Dalam Benny K. Heriawanto (Ed.), Prosiding $1^{\text {st }}$ Konferensi Nasional 2020: Hukum dan Birokrasi untuk Indonesia Tangguh. Fakultas Hukum, Fakultas Agama Islam, dan Fakultas Ilmu Administrasi, Universitas Islam Malang, hlm. 69.

${ }^{10}$ Aprista Ristyawati. (2020). Efektifitas Kebijakan Pembatasan Sosial Berskala Besar dalam Masa Pandemi Corona Virus 2019 oleh Pemerintah Sesuai Amanat UUD NRI Tahun 1945. Administrative Law and Governance Journal, Universitas Diponegoro, 3(2), hlm. 240.

${ }^{11}$ Isnaini Apri Dawati \& Shinta Rukmi Budiastuti. (2021). Peran Hukum saat Pandemi sebagai Terobosan dalam Mewujudkan Kesejahteraan Masyarakat. Logika: Jurnal Penelitian Universitas Kuningan, 12(1), hlm. 33. 
dijadikan rujukan dalam studi analisis, maupun pembentukan hukum ke depan, khususnya pembentukan hukum yang berkaitan dengan pelaksanaan hukum administrasi.

\section{METODE}

Tipe penelitian yang digunakan dalam penelitian ini adalah normatif-yuridis, yakni mengacu pada norma hukum peraturan perundang-undangan (statute approach). ${ }^{12}$ Sifat penelitian yang digunakan dalam penulisan ini adalah bersifat deskriptif-analitis, yang dianalisis secara kualitatif untuk menjawab permasalahan hukum yang dihadapi. Bahan hukum yang digunakan adalah bahan hukum primer, sekunder, dan tersier. Bahan hukum primer terdiri dari Peraturan Perundang-Undangan ataupun Putusan Pengadilan, yakni diolah atau dianalisis dengan melakukan taraf sinkronisasi hukum, yakni melakukan pelacakan dan pengukuran mengenai sejauh mana hukum positif tertulis yang ada sinkron atau serasi satu sama lainnya. Bahan hukum sekunder terdiri dari buku, jurnal, prosiding, koran atau majalah online, maupun pendapat ahli yang berfungsi sebagai unsur penunjang dalam membedah masalah dalam penelitian. Bahan hukum tersier terdiri dari kamus bahasa Indonesia, kamus ilmiah hukum, serta kamus bahasa Inggris yang berfungsi sebagai penunjang penelitian dalam menjelaskan istilah-istilah operasional yang digunakan.

\section{HASIL DAN PEMBAHASAN}

\section{A. Tinjauan Umum dan Perkembangan Hukum Administrasi Negara}

Dalam kajian hukum kenegaraan, disebutkan bahwa Hukum Tata Negara (HTN) dan Hukum Administrasi Negara (HAN) pada awalnya merupakan satu lingkup kajian yang sering disebut sebagai "staats en administratief recht". ${ }^{13}$ Dalam beberapa literatur, istilah HTN dan HAN masih digunakan secara bersamaan dengan istilah Constitutional and Administrative Law. ${ }^{14}$ Di Indonesia, kedua bidang hukum ini biasanya dikaji secara terpisah. Khusus untuk HAN merupakan istilah yang diambil dari kesepakatan pengasuh mata kuliah Hukum Administrasi Negara pada Pertemuan di Cibulan tanggal 26-28 Maret 1973. ${ }^{15}$

HAN merupakan bagian dari hukum publik, yaitu disiplin ilmu hukum yang mengatur bagaimana pemerintah bertindak serta bagaimana organ-organ negara menjalankan tugasnya. Dalam pandangan Ridwan H. R., ada dua aspek yang terkandung dalam HAN, antara lain yaitu: ${ }^{16}$

\footnotetext{
${ }^{12}$ Soerjono Soekanto. (1984). Pengantar Penelitian Hukum. Jakarta: UI Press, hal 20.

${ }^{13}$ Jimly Asshiddiqie. (2015). Pengantar Ilmu Hukum Tata Negara. Jakarta: PT. Raja Grafindo Persada, hlm. 41.

${ }^{14}$ Hilaire Barnett. (2004). Constitutional and Administrative Law. United Kingdom: Cavendish Publishing Limited. Lihat Chris Taylor. (2008). Constitutional and Administrative Law. London: Pearson Education Limited. Lihat juga Alex Carroll. (2007). Constitutional and Administrative Law. London: Pearson Education Limited.

${ }^{15}$ Philipus M. Hadjon, et al. (Eds.). (2008). Pengantar Hukum Administrasi Indonesia. Yogyakarta: Gadjah Mada University Press, hlm. 1.

${ }^{16}$ Ridwan H. R. (2014). Hukum Administrasi Negara. Jakarta: PT. Raja Grafindo Persada, hlm. 37.
} 
1. Aturan-aturan hukum yang mengatur dengan cara bagaimana alat-alat perlengkapan negara menjalankan tugasnya; serta

2. Aturan-aturan hukum yang mengatur hubungan hukum (rechtsbetrekking) antara alat perlengkapan administrasi negara dengan warga negara.

Konsep HAN sebagaimana diuraikan di atas juga tercermin dalam Pasal 1 angka 1 UU No. 30 Tahun 2014 yang menjelaskan bahwa:

"Administrasi Pemerintahan adalah tata laksana dalam pengambilan keputusan dan/atau tindakan oleh badan dan/atau pejabat pemerintahan."

Pelaksanaan pengambilan keputusan/tindakan administratif dalam kajian HAN selalu diawali dengan perolehan kewenangan, baik diperoleh melalui atribusi, delegasi, ataupun mandat. Selanjutnya, terdapat perbedaan pengertian yuridis antara wewenang dengan kewenangan dalam UU No. 30 Tahun 2014. Wewenang identik dengan hak, sebagaimana berdasarkan Pasal 1 angka 5 UU No. 30 Tahun 2014 yang menjelaskan bahwa:

"Wewenang adalah hak yang dimiliki oleh Badan dan/atau Pejabat Pemerintahan atau penyelenggara negara lainnya untuk mengambil keputusan dan/atau tindakan dalam penyelenggaraan pemerintahan."

Sedangkan kewenangan identik dengan kekuasaan, sebagaimana berdasarkan Pasal 1 angka 6 UU No. 30 Tahun 2014 yang menjelaskan bahwa:

"Kewenangan Pemerintahan yang selanjutnya disebut Kewenangan adalah kekuasaan Badan dan/atau Pejabat Pemerintahan atau penyelenggara negara lainnya untuk bertindak dalam ranah hukum publik."

Adapun bentuk penyelenggaraan fungsi administrasi negara dalam melayani warga negara, berdasarkan Pasal 1 angka 2 UU No. 30 Tahun 2014 menjelaskan bahwa:

"Fungsi Pemerintahan adalah fungsi dalam melaksanakan Administrasi Pemerintahan yang meliputi fungsi pengaturan, pelayanan, pembangunan, pemberdayaan, dan pelindungan."

Ketentuan di atas bertujuan untuk memberikan perlindungan hukum bagi warga negara dan aparatur pemerintahan. Yang dimaksud dengan perlindungan hukum bagi aparatur negara adalah agar para aparatur negara tidak terjerat sanksi hukum akibat melakukan tindakan sewenang-wenang.

Perkembangan HAN terbilang cukup dinamis karena mengikuti pesatnya perkembangan negara dan masyarakat. Menurut kesimpulan Bernardo Sordi yang menyatakan bahwa: ${ }^{17}$

"Perkembangan Hukum Administrasi Negara, baik dalam common law system maupun civil law system merefleksikan titik pangkal yang berbeda berkenaan dengan konsep administrasi sejak perang dunia kedua hingga abad ke-18."

\footnotetext{
${ }^{17}$ Bernardo Sordi. (2017). Révolution, Rechtsstaat and the Rule of Law: Historical Reflections on the Emergence and Development of Administrative Law. Dalam Susan Rose-Ackerman., Peter L. Lindseth, \& Blake Emerson (Eds.), Comparative Administrative Law. Cheltenham: Edward Elgar Publishing, hlm. 35.
} 
Salah satu perubahan yang mempengaruhi perkembangan HAN adalah pergesaran paradigma hukum administrasi itu sendiri. Dalam draf laporan Kompendium Bidang Hukum Administrasi BPHN Kemenkumham yang diketuai oleh Andhika Danesjvara, menyebutkan bahwa salah satu pergeseran paradigma yang timbul dalam hukum administrasi adalah dikotomi politik dan administrasi publik. ${ }^{18}$ Lebih lanjut, dengan mengutip pendapat Frank J. Goodnow, bahwa:19

"Pemerintah mempunyai dua fungsi yang berbeda, yaitu fungsi politik dan fungsi administrasi. Fungsi politik berkaitan dengan pembuatan kebijakan, sedangkan fungsi administrasi berkaitan dengan pelaksanaan (eksekusi) kebijakan."

Pandangan di atas senada dengan apa yang diuraikan oleh Ridwan H. R., bahwa: ${ }^{20}$

"Pemerintah kadang-kadang tampil dengan dua wajah (twee petten), yakni sebagai wakil dari jabatan dan wakil dari badan hukum pemerintah."

Perkembangan pelaksanaan HAN pada dasarnya juga dipengaruhi oleh banyaknya peraturan dengan berbagai bentuk dan jenis dalam penyelenggaraan pemerintahan negara. Hal ini juga tergambar dalam uraian Jeremy Kessler dan Charles Sabel, yang menyebutkan bahwa: ${ }^{21}$

"The growing reliance on guidance - a kind of provisional 'rule' that invites its own revision or qualification- marks a break in the development of the administrative state on the order of the transition from regulation ... (Meningkatnya ketergantungan pada pedoman -semacam 'aturan' sementara yang mengundang revisi atau kualifikasinya- merupakan penanda keterlambatan dalam perkembangan administrasi negara atas urutan peralihan dari peraturan ...)."

Sedangkan menurut Joanna Bell, perkembangan HAN bisa saja berkembang secara stabil atau bahkan mengarah pada stagnasi, yang dimana dinamika tersebut disebabkan dari beberapa hal, antara lain: ${ }^{22}$

1. Peraturan perundang-undangan yang berubah-ubah;

2. Praktik internal administrasi yang tidak statis dan meningkat sehingga menimbulkan doktrin-doktrin baru;

3. Munculnya prinsip peninjauan kembali (judicial review) sehingga menimbulkan ketidakseragaman dalam konsep hukum administrasi.

Mengenai perkembangan hukum administrasi di Indonesia, Kompendium Bidang Hukum Administrasi BPHN Kemenkumham menyebutkan tiga asumsi dasar yang

\footnotetext{
${ }^{18}$ Andhika Danesjvara., et al. (2008). Draf Laporan Kompedium Bidang Hukum Administrasi. Jakarta: Badan Pembinaan Hukum Nasional, Kementerian Hukum dan Hak Asasi Manusia, hlm. 27-28.

${ }^{19}$ Ibid., hlm. 28.

${ }^{20}$ Ridwan H. R. (2014). Op. Cit., hlm. 69.

${ }^{21}$ Jeremy Kessler \& Charles Sabel. (2021). The Uncertain Future of Administrative Law. Daedalus: Journal of the American Academy of Arts and Sciences, 150(4), hlm. 1.

${ }^{22}$ Joanna Bell. (2020). Rethinking the Story of Cart v Upper Tribunal and its Implications for Administrative Law. Oxford Journal of Legal Studies, 39(1), hlm. 96.
} 
menjiwai konsep Hukum Administrasi Pemerintahan, sehingga diusulkan atau dijabarkan, antara lain yaitu: ${ }^{23}$

1. Dikotomi antara HTN dengan HAN sudah harus ditinggalkan dan bahkan mengintegrasikannya dalam satu bidang hukum, yakni Hukum Administrasi Negara/Publik.

2. Administrasi Pemerintahan pada dasarnya adalah administrasi negara/publik.

3. Substansi Administrasi Pemerintahan dari bidang hukum ini harus disesuaikan dengan perkembangan ilmu administrasi publik terkini, yang selama ini kurang mendapat porsi konsiderasi yang memadai dari para pakar HTN atau HAN.

\section{B. Instrumen Hukum Administrasi Negara dalam Pembentukan Kebijakan} Publik

Dalam kerangka HAN, Pemerintah mempunyai beberapa instrumen untuk menjalankan fungsinya, antara lain sebagai berikut.

\section{Peraturan Perundang-Undangan (Act)}

Pelaksanaan kebijakan negara dalam kerangka hukum administrasi yang dilaksanakan berdasarkan peraturan perundang-undangan merupakan wujud dari konsep negara hukum yang menghendaki agar setiap penyelenggaraan pemerintahan negara wajib dilaksanakan berdasarkan hukum. Dalam lingkup hukum ketatanegaraan, peraturan perundang-undangan merupakan instrumen hukum yang dibentuk baik oleh lembaga legislatif, eksekutif, maupun dibentuk oleh legislatif dan eksekutif untuk mendapat persetujuan bersama. ${ }^{24}$

\section{Keputusan Tata Usaha Negara (Verwaltungsakt)}

Keputusan Tata Usaha Negara merupakan pernyataan sepihak dari organ instansi pemerintah yang bertujuan untuk menciptakan, mengubah, ataupun menghilangkan hubungan-hubungan hukum. ${ }^{25}$ Terdapat istilah-istilah dalam Pasal-Pasal UU No. 30 Tahun 2014, antara lain yaitu:

a. Keputusan Administrasi Pemerintahan;

b. Keputusan Tata Usaha Negara; serta

c. Keputusan Administrasi Negara.

Semua istilah di atas disebut Keputusan, yakni ketetapan tertulis yang dikeluarkan oleh Badan dan/atau PejabatPemerintahan dalam penyelenggaraan pemerintahan. Berdasarkan Pasal 87 huruf b UU No. 30 Tahun 2014, mengatur bahwa:

\footnotetext{
${ }^{23}$ Andhika Danesjvara., et al. (2008). Op. Cit., hlm. 129.

${ }^{24}$ Tubagus Muhammad Nasarudin. (2016). Asas dan Norma Hukum Administrasi Negara dalam Pembuatan Instrumen Pemerintahan. Jurnal Hukum Novelty, Universitas Ahmad Dahlan, 7(2), hlm. 141.

${ }^{25}$ Yodi Martono Wahyunadi. (2016). Kompetensi Absolut Pengadilan Tata Usaha Negara dalam Konteks Undang-Undang Nomor 30 Tahun 2014 tentang Administrasi Pemerintahan. Jurnal Hukum dan Peradilan, Mahkamah Agung RI, 5(1), hlm. 137.
} 
"Dengan berlakunya Undang-Undang ini, Keputusan Tata Usaha Negara ... harus dimaknai sebagai Keputusan Badan dan/atau Pejabat Tata Usaha Negara di lingkungan eksekutif, legislatif, yudikatif, dan penyelenggara negara lainnya."

Frasa "dan penyelenggara negara lainnya" dalam ketentuan di atas bisa saja mengundang perdebatan. Misalnya, bagaimana dengan keputusan yang dikeluarkan oleh badan hukum privat swasta yang juga menjalankan fungsi pemerintahan negara, apakah dapat dikualifikasikan ke dalam organ pemerintahan. Diketahui bahwa dalam perkembangan pemerintahan negara, pihak swasta juga diberikan porsi untuk mengelola kebijakan negara.

\section{Peraturan Kebijakan (Freies Ermessen/Discretionary Power)}

Peraturan kebijakan biasanya disebut dengan peraturan semu atau pseudo wetgeving yang berfungsi manakala tidak ditemukan suatu peraturan yang melandasi tindakan pemerintah, namun bersifat urgen terhadap permasalahan yang dihadapi pemerintah. ${ }^{26}$ Istilah Peraturan Kebijakan tidak ditemukan dalam UU No. 30 Tahun 2014, namun memiliki makna yang sama dengan istilah Diskresi.

\section{Perencanaan (Het Plan)}

Dalam penyelenggaraan pemerintahan negara, pemerintah wajib mencanangkan rencana-rencana pemerintah dalam suatu periode tertentu, yang biasa dituangkan berupa RPJM ataupun RPJP. ${ }^{27}$ Penjelasan Pasal 14 ayat (7) dalam lampiran UU No. 30 Tahun 2014, KTUN erat kaitannya dengan rencana-rencana kerja pemerintah.

\section{Perizinan (Concesie)}

Berdasarkan UU No. 30 Tahun 2014, terdapat sedikit perbedaan pengertian antara izin, konsesi, dan dispensasi. Berdasarkan Pasal 1 angka 19 UU No. 30 Tahun 2014, menjelaskan bahwa:

"Izin adalah Keputusan Pejabat Pemerintahan yang berwenang sebagai wujud persetujuan atas permohonan Warga Masyarakat sesuai dengan ketentuan peraturan perundang-undangan."

Berdasarkan Pasal 1 angka 20 UU No. 30 Tahun 2014, menjelaskan bahwa:

"Konsesi adalah Keputusan Pejabat Pemerintahan yang berwenang sebagai wujud persetujuan dari kesepakatan Badan dan/atau Pejabat Pemerintahan dengan selain Badan dan/atau Pejabat Pemerintahan dalam pengelolaan fasilitas umum dan/atau sumber daya alam dan pengelolaan lainnya sesuai dengan ketentuan peraturan perundangundangan."

\footnotetext{
${ }^{26}$ Victor Imanuel W. Nalle. (2016). Kedudukan Peraturan Kebijakan dalam Undang-Undang Administrasi Pemerintahan. Refleksi Hukum: Jurnal Ilmu Hukum, Universitas Kristen Satya Wacana, 10(1), hlm. 3.

${ }^{27}$ Wendi Suprapto Padang \& Heri Kusmanto. (2015). Perencanaan Partisipatif dalam Proses Penyusunan Rencana Pembangunan Jangka Menengah Daerah Kabupaten Dairi Tahun 2014-2019. Jurnal Administrasi Publik (Public Administration Journal), Universitas Medan Area, 5(2), hlm. 198.
} 
Berdasarkan Pasal 1 angka 21 UU No. 30 Tahun 2014, menjelaskan bahwa:

"Dispensasi adalah Keputusan Pejabat Pemerintahan yang berwenang sebagai wujud persetujuan atas permohonan Warga Masyarakatyang merupakan pengecualian terhadap suatu larangan atau perintah sesuai dengan ketentuan peraturan perundang-undangan."

Namun pada hakikatnya, baik izin, konsesi, maupun dispensasi adalah izin karena mengandung adhesi dan kontrak satu sisi. ${ }^{28}$ Hal ini berbeda dengan kontrak dalam lingkup hukum perdata, yang didasarkan pada kesesuaian dengan kehendak.

\section{Hukum Keperdataan}

Selain bertindak dengan menggunakan hukum publik, pemerintah juga dapat bertindak berdasarkan instrument hukum keperdataan. ${ }^{29}$ Misalnya menjalin kerja sama dengan pihak swasta atau dalam lalu lintas hukum perdata seperti jual beli.

\section{Perkembangan dan Urgensi Hukum Administrasi sebagai Alternatif Kebijakan Hukum dalam Masa Pandemi Covid-19}

Jika dicermati dengan teliti, pembentukan dan penetapan UU No. 2 Tahun 2020 sesungguhnya mencerminkan perintah yang menjadi substansi dari praktik hukum administrasi, yakni pembentukan instrument hukum dengan tidak melibatkan lembaga legislatif. Dasar pemikiran ini setidaknya menyangkut dengan empat hal, antara lain yaitu:

1. Penetapan UU No. 2 Tahun 2020 diawali dengan Penetapan Perpu No. 1 Tahun 2020, yang merupakan prerogratif Presiden, meskipun perihal penetapannya dilakukan oleh DPR;

2. Terdapat materi muatan dalam UU No. 2 Tahun 2020 yang mendelegasikan kewenangan dari atasan ke bawahan;

3. Bahkan, apabila merujuk pada Pasal 27 ayat (3) UU No. 2 Tahun 2020, UndangUndang a quo bukan termasuk obyek gugatan pengadilan tata usaha negara;

4. Tidak adanya RUU yang berkaitan dengan Covid-19 dalam Prolegnas 20202024, secara tidak langsung memberikan kewenangan kepada pemerintah eksekutif untuk membentuk kebijakan-kebijakan di masa pandemi.

Hal ini membuktikan bahwa kebijakan pemerintah yang tempuh dalam masa pandemi sarat dengan instrumen hukum administrasi karena tidak melalu proses wetgeving dan rechtspraak.

\footnotetext{
${ }^{28}$ Faizal Kurniawan \& Ayik Parameswary. (2014). Konstruksi Hukum Perlindungan Adhered Party dalam Kontrak Adhesi yang Digunakan dalam Transaksi Bisnis. Perspektif: Kajian Masalah Hukum dan Pembangunan, Universitas Wijaya Kusuma Surabaya, 19(3), hlm. 146.

${ }^{29}$ H. Herman. (2015). Perlindungan Hukum Warga Negara terhadap Tindakan Pemerintah dalam Membuat Keputusan Administrasi Negara. Jurnal Komunikasi Hukum, Universitas Pendidikan Ganesha, 1(1), hlm. 44 .
} 
Walaupun dibentuk dalam keadaan mendesak, namun perlu diakui bahwa dari segi formil, pembentukan dan penetapan UU No. 2 Tahun 2020 pada dasarnya cukup memadai, manakala ditinjau dari UU No. 15 Tahun 2019. Pengesahan UU No. 2 Tahun 2020 yang diawali oleh Perpu juga telah mencerminkan Putusan Mahkamah Konstitusi Nomor 138/PUU-VII/2009. Hanya saja, salah satu bentuk kekurangan UU No. 2 Tahun 2020 adalah tidak terdapat bab tentang ketentuan umum yang mempunyai kedudukan penting dalam memberikan definisi operasional mengenai istilah-istilah yang digunakan, terlepas dari pasal-pasal kontroversial yang terdapat dalam materi muatan Undang-Undang a quo.

Namun kekurangan-kekurangan tersebut tidak serta merta membuat fungsi administrasi negara tidak berjalan, sehingga pembentukan instrumen hukum berupa peraturan pelaksana dapat diminimalisir. Dalam prakteknya terkadang peraturan pelaksana memuat materi yang secara utuh telah dijabarkan namun ditemukan kembali dalam peraturan pelaksana. Kebiasaan-kebiasaan tersebut juga masih dijumpai selama pandemi. Misalnya, diawali dengan UU No. 2 Tahun 2020, kemudian didelegasikan kepada misalnya menteri, lalu dibentuk Peraturan Menteri. Dari Peraturan Menteri tersebut kemudian dibentuk Instruksi Menteri, misalnya, Instruksi Menteri Dalam Negeri Nomor 4 Tahun 2020.

Pelaksanaan administrasi pemerintahan yang dilakukan dengan memproduksi peraturan yang relatif banyak, juga berimplikasi pada masalah pengawasan. Sebagaimana diketahui bersama bahwa dengan menjamurnya lembaga negara yang independen, maka fungsi pengawasan pemerintahan negara dialokasikan sesuai dengan jumlah organ pemerintahan. Secara umum, sistem pengawasan di Indonesia berujung pada dua sistem, yakni:

1. Adanya lembaga yang mengawasi sebuah lembaga atau organ negara tertentu;

2. Pengawasan dilakukan dengan menggunakan sistem pengawasan tanpa membentuk lembaga atau organ pengawas tertentu.

Namun dalam praktik, kerja-kerja pengawasan ini tidak sistematis karena berkaitan dengan pengawasan yang dilakukan oleh lembaga legislatif.

Pada masa pandemi yang dimaknai sebagai situasi extraordinary, kebijakan pemerintahan negara semestinya ditempuh dengan langkah-langkah ekstra dan cepat. Dengan adanya ketentuan "ekstra" dalam Pasal 27 ayat (3), terlepas dari kontroversinya, sebenarnya ketentuan ini membuka peluang bagi akselerasi hukum administrasi dalam pembentukan kebijakan, yang tidak harus didahului dengan membentuk peraturan-peraturan pelaksana. Hal ini masih sesuai dengan salah satu lingkup diskresi sebagaimana berdasarkan Pasal 1 angka 9 UU No. 30 Tahun 2014, menjelaskan bahwa "...dalam hal peraturan perundang-undangan yang memberikan pilihan, tidak mengatur...". Di sisi lain, sejauh ini belum ada Putusan Pengadilan yang menganulir materi muatan dalam UU No. 2 Tahun 2020, 
yang memberikan peluang untuk mengembangkan hukum administrasi dalam kaitannya dengan UU No. 2 Tahun 2020.

Ada beberapa faktor yang mendukung pelaksanaan kebijakan negara di era pandemi Covid-19 dengan menggunakan instrumen hukum administrasi, antara lain yaitu:

1. Hukum administrasi merupakan suatu sistem yang relevan dengan bentuk susunan negara kesatuan dengan sistem pemerintahan presidensial. Walaupun dalam perkembangan pemerintahan negara dewasa ini menunjukan adanya pelaksanaan otonomi daerah dengan asas desentralisasi, namun sifat asli dari susunan negara kesatuan dengan sistem pemerintahan presidensil menghendaki adanya pembentukan kebijakan negara yang tersentralisasi tetapi bukan yang bersifat sentralistis-otokratis. Hal ini akan mempengaruhi pengambilan keputusan oleh pemerintah dengan cepat tanpa melalui proses birokrasi yang berkepanjangan.

2. Instrumen hukum administrasi relatif lebih efisien. Pembentukan kebijakan negara pada umumnya dilakukan dengan melibatkan cabang-cabang kekuasaan negara, termasuk pengaruh-pengaruh politik. Hukum administrasi relatif lebih efisien karena memuat petunjuk teknis dalam menangani masalah kongkrit yang dihadapi pemerintah. Selain itu, pembentukan instumen hukum administrasi cenderung lebih cepat, hal ini sangat sejalan dengan kondisi penyebaran pandemi Covid-19 yang pada kenyataannya telah menimbulkan kejenuhan sosial. Dengan instrumen hukum administrasi, penyelenggara negara dan masyarakat dapat melakukan perbuatan hukum tanpa birokrasi dan regulasi yang berbelit-belit.

3. Penerapan instrumen hukum administrasi lebih fleksibel karena dapat dibentuk tanpa didahului oleh atribusi undang-undang, sepanjang tidak bertentangan dengan peraturan perundang-undangan. Bahkan, instrumen hukum administrasi dapat dibentuk dan ditetapkan tanpa didasarkan pada atribusi peraturan yang lebih tinggi karena pelaksanaan negara hukum tidak hanya didasarkan pada peraturan perundang-undangan, tetapi juga berdasarkan asas "salus populi suprema lex esto" serta asas "vox populi vox dei". Adanya ruang pembentukan hukum melalui instrumen hukum adminsitrasi yang relatif lebih cepat serta berbiaya ringan juga selaras dengan semangat penyederhanaan regulasi yang sedang berproses, terutama instrumen hukum administrasi yang berbentuk keputusan.

4. Pemberian perlindungan hukum yang lebih cepat. Pada dasarnya, efektifitas pemberian perlindungan hukum terletak pada bagaimana warga negara merasa puas dengan penyelesaian masalah-masalah hukum. Perlindungan hukum melalui mekanisme peradilan tidak selalu memberikan perlindungan hukum yang sesuai dengan kehendak batin pencari keadilan yang posisinya relatif lemah. Dengan instrumen hukum administrasi, perlindungan hukum 
dapat dilakukan secara langsung ketika ada pengaduan dari warga negara yang kepentingannya berhadapan dengan kebijakan pemerintah, baik kebijakan yang bersifat publik maupun keperdataan.

\section{KESIMPULAN DAN SARAN}

Berdasarkan uraian-uraian diatas, maka dapat disimpulkan hal-hal sebagai berikut, Pertama, instrumen hukum administrasi dalam pembentukan kebijakan publik berkembang secara dinamis dari waktu ke waktu seiring dengan kebutuhan negara dan warga negara. Terdapat beberapa instrumen hukum administrasi yang dapat digunakan dalam penyelenggaraan pemerintahan, yakni peraturan perundangundangan; KTUN (verwaltungsakt); peraturan kebijakan (freies ermessen); perencanaan (het plan); perizinan (concesie); dan instrument hukum keperdataan. Adapun beberapa hal yang mempengaruhi perkembangan hukum administrasi, yakni peraturan perundang-undangan yang berubah-ubah; praktik internal administrasi yang tidak statis dan meningkat sehingga menimbulkan doktrin-doktrin baru; dan proses judicial review sehingga memuncul ketidakseragaman dalam konsep hukum administrasi. Kedua, perkembangan dan urgensi hukum administrasi sebagai alternatif kebijakan pemerintah dalam masa pandemi Covid-19 dapat diketahui oleh beberapa indikator, yakni penyusunan peraturan yang nyaris tidak melibatkan legislatif; materi muatan peraturan-peraturan selama pandemi yang mendelegasikan kewenangan dari atasan ke bawahan, yang merupakan wujud pelaksanaan hukum administrasi; terdapat ketentuan dalam Pasal 27 ayat (3) UU No. 2 Tahun 2020 yang menyebutkan bahwa Undang-Undang a quo bukan termasuk obyek gugatan pengadilan tata usaha negara; serta tidak adanya RUU dalam Prolegnas 2020-2024 yang mencerminkan adanya ruang akselerasi dalam penanggulangan Covid-19 dengan menggunakan instrumen hukum administrasi pemerintahan. Selain itu, pembentukan instrumen hukum administrasi negara relatif cepat dan berbiaya ringan, sesuai dengan kondisi penyebaran pandemi Covid-19 yang telah menunjukkan kejenuhan sosial, sehingga diperlukan birokrasi yang tidak berbelit-belit dan prima.

\section{DAFTAR PUSTAKA}

Abdul Basid Fuadi., Zaka Firma Aditya., \& Rizkisyabana Yulistyaputri. (2020). Pentingnya Evidence Based Policy Making dalam Pembuatan Kebijakan Publik di Era Pandemi. Dalam Benny K. Heriawanto (Ed.), Prosiding $1^{\text {st }}$ Konferensi Nasional 2020: Hukum dan Birokrasi untuk Indonesia Tangguh (hlm. 69-81). Fakultas Hukum, Fakultas Agama Islam, dan Fakultas Ilmu Administrasi, Universitas Islam Malang. doi: https://dx.doi.org/10.2139/ssrn.3776955

Administrator. (2020, 10 Februari). Program Legislasi Nasional 2020-2024. Sekretariat Jenderal DPR RI. Diakses dari https://www.dpr.go.id/uu/prolegnas-long-list, pada tanggal 12 Februari 2020.

Alex Carroll. (2007). Constitutional and Administrative Law. London: Pearson Education Limited. 
Andhika Danesjvara., et al. (2008). Draf Laporan Kompedium Bidang Hukum Administrasi. Jakarta: Badan Pembinaan Hukum Nasional, Kementerian Hukum dan Hak Asasi Manusia.

Aprista Ristyawati. (2020). Efektifitas Kebijakan Pembatasan Sosial Berskala Besar dalam Masa Pandemi Corona Virus 2019 oleh Pemerintah Sesuai Amanat UUD NRI Tahun 1945. Administrative Law and Governance Journal, Universitas Diponegoro, 3(2), hlm. 240-248. doi: https://doi.org/10.14710/alj.v3i2.240-249

Bernardo Sordi. (2017). Révolution, Rechtsstaat and the Rule of Law: Historical Reflections on the Emergence and Development of Administrative Law. Dalam Susan Rose-Ackerman., Peter L. Lindseth, \& Blake Emerson (Eds.), Comparative Administrative Law (hlm. 23-37). Cheltenham: Edward Elgar Publishing. doi: https://doi.org/10.4337/9781784718671.00008

Chris Taylor. (2008). Constitutional and Administrative Law. London: Pearson Education Limited.

Faizal Kurniawan \& Ayik Parameswary. (2014). Konstruksi Hukum Perlindungan Adhered Party dalam Kontrak Adhesi yang Digunakan dalam Transaksi Bisnis. Perspektif: Kajian Masalah Hukum dan Pembangunan, Universitas Wijaya Kusuma Surabaya, 19(3), hlm. 144-152. doi: http://dx.doi.org/10.30742/perspektif. v19i3.17

H. Herman. (2015). Perlindungan Hukum Warga Negara terhadap Tindakan Pemerintah dalam Membuat Keputusan Administrasi Negara. Jurnal Komunikasi Hukum, Universitas Pendidikan Ganesha, 1(1), hlm. 43-59. doi: http://dx.doi. org/10.23887/jkh.v1i1.5012

Hilaire Barnett. (2004). Constitutional and Administrative Law. United Kingdom: Cavendish Publishing Limited.

Ide Prima Hadiyanto. (2021). Pendaftaran Gugatan Online di Pengadilan di Era Pandemi Covid-19. Jurnal Ilmiah Fenomena, Universitas Abdurachman Saleh, 18(1), hlm. 2048-2062.

Isnaini Apri Dawati \& Shinta Rukmi Budiastuti. (2021). Peran Hukum saat Pandemi sebagai Terobosan dalam Mewujudkan Kesejahteraan Masyarakat. Logika: Jurnal Penelitian Universitas Kuningan, 12(1), hlm. 33-41.

James Boylan., et al. (2021). Boredom in the COVID-19 Pandemic: Trait Boredom Proneness, the Desire to Act, and Rule-Breaking. Personality and Individual Differences, Elsevier, 171, hlm. 1-6. doi: https://doi.org/10.1016/j. paid.2020.110387

Jeremy Kessler \& Charles Sabel. (2021). The Uncertain Future of Administrative Law. Daedalus: Journal of the American Academy of Arts and Sciences, 150(4), hlm. 1-19. doi: https://dx.doi.org/10.2139/ssrn.3780796

Jimly Asshiddiqie. (2015). Pengantar Ilmu Hukum Tata Negara. Jakarta: PT. Raja Grafindo Persada.

Joanna Bell. (2020). Rethinking the Story of Cart v Upper Tribunal and its Implications for Administrative Law. Oxford Journal of Legal Studies, 39(1), hlm. 74-99. doi: https://doi.org/10.1093/ojls/gqaa057 
Klaus Schwab \& Thierry Malleret. (2020). Covid-19: The Great Reset. Switzerland: Forum Publishing.

Lutfia Rizkyatul Akbar. (2020). Analisis Kinerja Direktorat Jendral Pajak dalam Optimalisasi Penerimaan Pajak di Era-Pandemi Covid 19. JABE (Journal of Applied Business and Economic), Universitas Indraprasta PGRI, 7(1), hlm. 98-110. doi: http://dx.doi.org/10.30998/jabe.v7i1.7787

Peraturan Pemerintah Pengganti Undang-Undang Republik Indonesia Nomor 1 Tahun 2020 tentang Kebijakan Keuangan Negara dan Stabilitas Sistem Keuangan untuk Penanganan Pandemi Corona Virus Disease 2019 (COVID-19) dan/atau Dalam Rangka Menghadapi Ancaman yang Membahayakan Perekonomian Nasional dan/atau Stabilitas Sistem Keuangan. (Lembaran Negara Republik Indonesia Tahun 2020 Nomor 87. Tambahan Lembaran Negara Republik Indonesia Nomor 6485).

Philipus M. Hadjon., et al. (Eds.). (2008). Pengantar Hukum Administrasi Indonesia. Yogyakarta: Gadjah Mada University Press.

Ridwan H. R. (2014). Hukum Administrasi Negara. Jakarta: PT. Raja Grafindo Persada.

Sandhy Handika., Muhammad Ibnu Fajar Rahim., \& Rudi Pradisetia Sudirdja. (2020). Virtual Court Policy For Criminal Justice on Corona Virus Disease Pandemic. Substantive Justice International Journal of Law, Universitas Muslim Indonesia, 3(1), hlm. 74-93. doi: http://dx.doi.org/10.33096/substantivejustice.v3i1.67

Soerjono Soekanto. (1984). Pengantar Penelitian Hukum. Jakarta: UI Press.

Undang-Undang Republik Indonesia Nomor 12 Tahun 2011 tentang Pembentukan Peraturan Perundang-Undangan. (Lembaran Negara Republik Indonesia Tahun 2011 Nomor 82. Tambahan Lembaran Negara Republik Indonesia Nomor 5234).

Undang-Undang Republik Indonesia Nomor 30 Tahun 2014 tentang Administrasi Pemerintahan. (Lembaran Negara Republik Indonesia Tahun 2014 Nomor 292. Tambahan Lembaran Negara Republik Indonesia Nomor 5601).

Undang-Undang Republik Indonesia Nomor 15 Tahun 2019 tentang Perubahan Atas Undang-Undang Nomor 12 Tahun 2011 tentang Pembentukan Peraturan Perundang-Undangan. (Lembaran Negara Republik Indonesia Tahun 2019 Nomor 183. Tambahan Lembaran Negara Republik Indonesia Nomor 6398).

Undang-Undang Republik Indonesia Nomor 2 Tahun 2020 tentang Penetapan Peraturan Pemerintah Pengganti Undang-Undang Nomor 1 Tahun 2020 tentang Kebijakan Keuangan Negara dan Stabilitas Sistem Keuangan untuk Penanganan Pandemi Corona Virus Disease 2019 (COVID-19) dan/atau Dalam Rangka Menghadapi Ancaman yang Membahayakan Perekonomian Nasional dan/ atau Stabilitas Sistem Keuangan Menjadi Undang-Undang. (Lembaran Negara Republik Indonesia Tahun 2020 Nomor 134. Tambahan Lembaran Negara Republik Indonesia Nomor 6516).

Tubagus Muhammad Nasarudin. (2016). Asas dan Norma Hukum Administrasi Negara dalam Pembuatan Instrumen Pemerintahan. Jurnal Hukum Novelty, Universitas Ahmad Dahlan, 7(2), hlm. 139-154. doi: http://dx.doi.org/10.26555/novelty. v7i2.a5463 
Victor ImanuelW. Nalle. (2016). Kedudukan Peraturan Kebijakan dalam Undang-Undang Administrasi Pemerintahan. Refleksi Hukum: Jurnal Ilmu Hukum, Universitas Kristen Satya Wacana, 10(1), hlm. 1-16. doi: https://doi.org/10.24246/jrh.2016. v10.i1.p1-16

Wendi Suprapto Padang \& Heri Kusmanto. (2015). Perencanaan Partisipatif dalam Proses Penyusunan Rencana Pembangunan Jangka Menengah Daerah Kabupaten Dairi Tahun 2014-2019. Jurnal Administrasi Publik (Public Administration Journal), Universitas Medan Area, 5(2), hlm. 195-216.

Yodi Martono Wahyunadi. (2016). Kompetensi Absolut Pengadilan Tata Usaha Negara dalam Konteks Undang-Undang Nomor 30 Tahun 2014 tentang Administrasi Pemerintahan. Jurnal Hukum dan Peradilan, Mahkamah Agung RI, 5(1), hlm. 135 154.

\footnotetext{
A. Sakti R. S. Rakia. (2021). Perkembangan dan Urgensi Instrumen Hukum Administrasi I Pasca Penetapan Undang-Undang Nomor 2 Tahun 2020 pada Masa Pandemi Covid-19. SIGn Jurnal Hukum, CV. Social Politic Genius (SIGn), 2(2), hlm. 157-173. doi: https:// ' I doi.org/10.37276/sjh.v2i2.106
} 